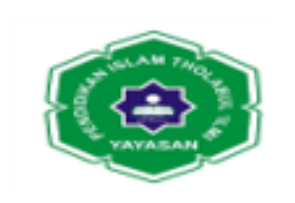

Jurnal Ilmiah METADATA

\title{
HUBUNGAN DISIPLIN KERJA DAN SIKAP INOVATIF DENGAN KINERJA GURU SMA NEGERI 14 MEDAN
}

\author{
Ahmad Karim \\ Universitas Pembinaan Masyarakat Indonesia \\ email : ahmadkarimk@yahoo.co.id
}

\begin{abstract}
ABSTRAK
Guru sangat berperan dalam membantu perkembangan peserta didik untuk mewujudkan tujuan hidupnya secara optimal. Sebagai seorang yang profesional guru harus memiliki kompetensi keguruan yang cukup. Guru yang memiliki kinerja yang tinggi pada dasarnya dapat menjalankan tugasnya secara tanggung jawab. Penelitian ini mempunyai tujuan untuk mengetahui hubungan antara disiplin kerja dengan kinerja guru SMA Negeri 14 Medan, hubungan antara sikap inovatif dengan kinerja guru SMA Negeri 14 Medan dan hubungan antara disiplin kerja dan sikap inovatif secara simultan dengan kinerja guru SMA Negeri 14 Medan. Populasi dalam penelitian ini adalah semua guru yang mengajar di SMA Negeri 14 Medan, dengan jumlah keseluruhan sebanyak 50 orang guru. Seluruh populasi yang berjumlah 50 orang diambil sebagai sampel. Teknik pengumpulan data dalam penelitian ini adalah kuesioner, wawancara dan studi dokumentasi. Sedangkan teknik analisis data yang digunakan adalah uji asumsi klasik, korelasi, uji t, uji F dan koefisien determinasi. Hasil penelitian menunjukkan bahwa variabel disiplin kerja mempunyai hubungan yang positif dan signifikan dengan kinerja guru SMA Negeri 14 Medan, Semakin tinggi tingkat disiplin guru maka kinerja guru juga akan semakin tinggi. Variabel sikap inovatif mempunyai hubungan yang positif dan signifikan dengan kinerja guru SMA Negeri 14 Medan, Semakin inovatif sikap guru maka kinerja guru juga akan semakin tinggi. Variabel disiplin kerja dan sikap inovatif secara serempak mempunyai hubungan yang signifikan dengan kinerja guru SMA Negeri 14 Medan. Koefisien determinasi sebesar 89,2 \% variasi kinerja guru dapat dijelaskan oleh disiplin kerja dan sikap inovatif secara serempak, sedangkan sisanya 10,80\% lagi dijelaskan oleh faktor lain, yaitu seperti variabel motivasi dan gaya kepemimpinan.
\end{abstract}

Kata Kunci: Disiplin Kerja, Sikap Inovatif, Kinerja Guru

\section{WORK DISCIPLINE RELATIONS AND INNOVATIVE ATTITUDES WITH TEACHERS' PERFORMANCE IN SMA NEGERI 14 MEDAN}

\begin{abstract}
The teacher is very instrumental in helping the development of students to realize their life goals optimally. As a professional teacher must have sufficient teacher competency. Teachers who have high performance can basically carry out their duties responsibly. This study aims to determine the relationship between work discipline and teacher performance in SMA Negeri 14 Medan, the relationship between innovative attitudes and teacher performance in SMA Negeri 14 Medan
\end{abstract}




\section{당}

\section{Jurnal Ilmiah METADATA}

and the relationship between work discipline and innovative attitudes simultaneously with the teacher's performance in SMA Negeri 14 Medan. The population in this study were all teachers who taught in SMA Negeri 14 Medan, with a total of 50 teachers. The entire population of 50 people was taken as a sample. Data collection techniques in this study are questionnaires, interviews and documentation studies. While the data analysis technique used is the classical assumption test, correlation, $t$ test, $F$ test and coefficient of determination. The results showed that the variables of work discipline had a positive and significant relationship with the teacher performance of SMA Negeri 14 Medan, The higher the level of teacher discipline, the higher the teacher's performance will be. Variables of innovative attitudes have a positive and significant relationship with teacher performance in SMA Negeri 14 Medan, The more innovative the teacher's attitude is, the higher the teacher's performance will be. Work discipline variables and innovative attitudes simultaneously have a significant relationship with teacher performance in SMA Negeri 14 Medan, The coefficient of determination of $89.2 \%$ variations in teacher performance can be explained by work discipline and innovative attitude simultaneously, while the remaining $10.80 \%$ is explained by other factors, such as motivation and leadership style variables.

\section{Keywords: Work Discipline, Innovative Attitude, Teacher Performance}

\section{PENDAHULUAN}

Memasuki era globalisasi dengan kemajuan ilmu pengetahuan, teknologi dan informasi, maka dunia pendidikan harus mempersiapkan dari dini dalam melatih peserta didik untuk mampu belajar secara mandiri dan mampu bersaing di pasar global.

Dalam penyelenggaraan pendidikan dapat dipengaruhi oleh berbagai komponen pendukung diantaranya ad alah komponen guru, peserta didik, sarana dan prasarana pendidikan, pengelolaan dan pembiayaan. Keseluruhan komponen tersebut saling keterkaitan dan sangat mempengaruhi dalam keberhasilan dan peningkatan kualitas pendidikan.

Guru memiliki peran yang penting, merupakan posisi strategis, dan bertanggung jawab dalam pendidikan nasional. Guru memiliki tugas sebagai pendidik, pengajar dan pelatih. Mendidik berarti meneruskan dan mengembangkan nilai-nilai hidup. Sedangkan mengajar berarti meneruskan dan mengembangkan ilmu, pengetahuan dan teknologi. Melatih berarti meneruskan dan mengmbangkan keterampilan-keterampilan pada siswa.

Guru merupakan komponen paling penting dalam menciptakan sumber daya manusia yang rasional. Oleh sebab itu dibutuhkan sikap profesionalisme guru dalam proses pembelajaran. Guru sebagai tenaga pendidik adalah tokoh yang paling banyak bergaul dan berinteraksi dengan murid dibandingkan dengan personel lain disekolah. Guru bertugas merencanakan dan melakanakan pembelajaran, menilai hasil pembelajaran, melakukan bimbingan dan pelatihan, melakukan pengkajian dan penelitian dan membuka komunikasi dengan masyarakat.Baik atau buruknya perilaku atau cara mengajar guru sangat mempengaruhi citra lembaga pendidikan. 


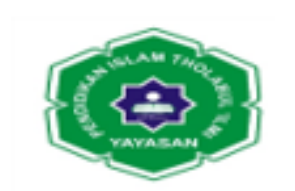

\section{Jurnal Ilmiah METADATA}

Kegiatan pendidikan disekolah menempatkan sekolah sebagai salah satu institusi sosial yang keberad aannya melaksanakan kegiatan pembinaan potensi guru dan transpormasi nilai budaya bangsa yang bertanggung jawab terhadap proses pengembangan kemampuan individualitas, moralitas dan sosialitas guru disekolah.

Untuk meningkatkan kualitas kinerja guru sangat sulit dan berkaitan dengan berbagai faktor yang mempengaruhinya diantaranya guru tidak semaksimal mungkin mempersiapkan pembelajaran dengan baik, kehadiran yang sangat rendah serta tidak menunjukkan kemampuan sesuai dengan kompetensi yang dimiliki seorang guru. Guru sebagai satu komponen dari beberapa komponen sekolah perlu mendapat pembinaan secara terus menerus. Hal ini dilakukan untuk memelihara perwujudan kinerja guru.

Berdasarkan Peraturan Menteri Pendidikan Republik Indonesia Nomor 16 tahun 2007 tentang Standar Kualifikasi Akademik dan Kompetensi Guru dijelaskan bahwa kompetensi guru dikembangkan secara utuh dari 4 kompetensi utama yaitu a) Kompetensi Pedagogik yaitu kompetensi tentang pemahaman terhadap peserta didik, perencanaan dan pelaksanaan pembelajaran, evaluasi hasil belajar dan pengembangan peserta didik, b) Kompetensi kepribadian yaitu kompetensi tentang kemampuan personal yang mencerminkan kepribadian yang mantap, stabil, dewasa, arif dan berwibawa menjadi teladan bagi peserta didik dan berakhlak mulia, c) Kompetensi Sosial yaitu kompetensi tentang kemampuan berkomunikasi dan bergaul secara efektif dengan peserta didik, sesama pendidik, tenaga kependidikan, orang tua dan loingkungan, dan d) Kompetensi Profesional yaitu kompetensi tentang penguasaan materi pembelajaran secara luas dan mendalam.

Guru yang memiliki kinerja yang tinggi pada dasarnya dapat menjalankan tugasnya secara tanggung jawab. Anwar (2009:91) mengemukakan bahwa rasa tanggung jaw ab ada pada kemand irian dalam bentuk kemampuan dalam mengambil keputusan yang mengandung wibawa pendidikan baik secara akademis maupun praktik. Dalam melakukan pelayanan pendidikan, guru sebagai pemimpin dan manager perlu membiasakan diri untuk (a) mengelola waktu, (b) memilih apa yang dapat dikontribusikan, (c) mampu mengidentifikasi dan memobilisasikan kekuatan efektivitas produksi, (d) mampu mengatur prioritas tugas, (e) mampu membuat keputusan secara efektif. Guru juga dituntut agar mampu membuat terobosan atau motivasi baru dalam rangka melaksanakan tugas sebagai pendidik. Serta memiliki disiplin kerja yang baik dan sikap inovatif terhadap institusi pendidikan sebagai wujud kinerja yang tinggi.

Kinerja guru pada dasarnya adalah kemampuan guru dalam mentransfer ilmu pengetahuan dan nilai-nilai kemasyarakatan ke peserta didik melalui proses belajar. Adapun faktor-faktor yang dapat digunakan untuk meningkatkan kinerja guru adalah disiplin kerja dan sikap inovatif, karena kedua faktor tersebut berkaitan langsung dengan proses belajar.

Disiplin kerja guru yang baik dapat dilihat dari tingginya kesadaran dalam mematuhi segala peraturan yang berlaku, dapat hadir pada setiap jam belajar dan tidak terlambat sesuai dengan waktu yang ditetapkan, serta melaksanakan pengajaran sesuai dengan silabus atau rencana pembelajaran yang ditetapkan. 


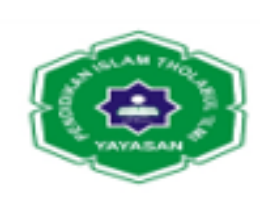

\section{Jurnal Ilmiah METADATA}

Pelaksanaan disiplin guru tentu akan menjadi faktor pendorong dalam peningkatan kinerjanya,.

Sikap inovatif dapat diartikan sebagai perilaku yang cenderung mudah menerima dan menerapkan gagasan baru, atau selalu berupaya menciptakan gagasan baru dan lebih baik dari yang telah ada. Dalam hal ini, sikap guru dalam berinovasi menjadi sangat penting mengingat guru merupakan 'aktor' atau pemain utama dalam proses belajar mengajar di kelas, sehingga setiap guru diharapkan agar selalu dapat menciptakan gagasan baru untuk membuat metode pembelajaran menjadi lebih efektif dan efisien. Setiap gagasan yang dapat meningkatkan kualitas belajar tentu akan meningkatkan kinerja guru dalam upaya menghasilkan siswa cerdas.

Berbagai variabel yang mempengaruhi kinerja guru baik secara empiris maupun konseptual seperti yang dikemukakan di atas dapat digunakan untuk memahami, memprediksi, dan menemukan alternatif fenomena permasalahan kinerja guru. Meskipun beberapa peneliti menemukan juga variabel yang sama dengan peneliti lainnya. Keadaan ini menunjukan bahwa berbagai variabel ditemukan secara empiris memberi pengaruh terhadap kinerja sehingga dalam melakukan penelitian tentang kinerja, peneliti mendapatkan peluang yang sangat besar untuk menemukan variabel-variabel yang akan diujinya, terutama dalam menjelaskan, memprediksi dan menemukan alternatif dari fenomena-fenomena permasalahan kinerja.

Gibson (2011:24) mengemukakan bahwa untuk mencapai kinerja yang baik perlu diperhatikan tiga kelompok variabel yang mempengaruhi kinerja yaitu variabel individu, psikologis, dan organisasi. Jika dihubungkan pengelompokan variabel yang mempengaruhi kinerja dalam pandangan Gibson dan beberapa hasil penelitian empiris tentang kinerja guru tentang efektivitas individu di dalam organisasi maka sesungguhnya penentu kinerja guru tersebut berada pada diri guru itu sendiri termasuk di dalamnya, disiplin kerja dan sikap inovatif.

SMA Negeri 14 Medan merupakan instansi publik yang melayani pendidikan siswa-siswi di sekolah. Sebagai instansi pendidikan, maka ukuran utama keberhasilan instansi secara keseluruhan adalah tingkat kecerdasan siswa-siswi, yang sekaligus menjadi gambaran kinerja dari para guru yang melaksanakan pengajaran di sekolah. Tingkat kecerdasarn siswa-siswi tersebut dapat dilihat dari hasil ujian nasional, seperti tertera pada Tabel 1.

Tabel 1.

Nilai Hasil Ujian Nasional SMA Negeri 14 Medan

\begin{tabular}{|lccl|}
\hline Mata & Tahun & Tahun & Perbandingan \\
Pelajaran & 2017 & $\mathbf{2 0 1 8}$ & \\
\hline Program & studi IPA: & & \\
Bahasa & 68.11 & 60.68 & Menurun \\
Indonesia & & & \\
Bahasa & 46.66 & 50.32 & Meningkat \\
Inggris & & &
\end{tabular}


Jurnal Ilmiah METADATA

\begin{tabular}{|lccl|} 
Matematika & 33.65 & 29.92 & Menurun \\
Pilihan & 46.82 & 44.52 & Menurun \\
\hline Jumlah & $\mathbf{1 9 5 . 2 4}$ & $\mathbf{1 8 5 . 4 4}$ & Menurun \\
\hline $\begin{array}{l}\text { Program studi IPS: } \\
\text { Bahasa }\end{array}$ & 53.50 & 52.71 & Menurun \\
$\begin{array}{l}\text { Indonesia } \\
\text { Bahasa }\end{array}$ & 31.19 & 35.60 & Meningkat \\
$\begin{array}{l}\text { Inggris } \\
\text { Matematika }\end{array}$ & 30.07 & 27.77 & Menurun \\
Pilihan & 45.27 & 40.14 & Menurun \\
\hline Jumlah & $\mathbf{1 6 0 . 0 3}$ & $\mathbf{1 5 6 . 2 2}$ & Menurun \\
\hline
\end{tabular}

Sumber: SMA Negeri 14 Medan

Berdasarkan Tabel 1 dapat dijelaskan bahwa kinerja guru SMA Negeri 14 masih tergolong rendah, karena ternyata jumlah nilai ujian nasional siswa-siswi didikannya justru mengalami penurunan. Terlihat bahwa nilai hasil ujian nasional untuk beberapa mata pelajaran pada tahun 2018 lebih rendah dibanding nilai hasil ujian nasional pada tahun 2017 kecuali pada mata pelajaran Bahasa Inggris.

Hasil belajar siswa tergantung pada kemampuan guru dalam mengelola pembelajaran. Kemampuan atau kompetensi guru dapat dilihat dari nilai ujian kompetensi guru atau disingkat dengan UKG, seperti tertera pada Tabel 2.

Tabel 2.

Distribusi Guru Berdasarkan Nilai Ujian Kompetensi Guru SMA Negeri 14

Medan

\begin{tabular}{|c|c|c|}
\hline Nilai UKG & $\begin{array}{c}\text { Jumlah } \\
\text { Guru } \\
\text { (jiwa) }\end{array}$ & Persen (\%) \\
\hline$<55$ & 30 & 60.00 \\
\hline$\geq 55$ & 20 & 40.00 \\
\hline Total & 50 & 100.00 \\
\hline
\end{tabular}

Sumber: SMA Negeri 14 Medan

Berdasarkan Tabel 2 dapat dijelaskan bahwa nilai UKG SMA Negeri 14 tergolong rendah. Rata-rata nilai UKG adalah 53,31, sementara standar UKG adalah 55,00. Sebagian besar guru mempunyai nilai UKG di bawah standar, yaitu $60, .00 \%$, sedangkan guru dengan nilai UKG di atas standar lebih sedikit, yaitu 40,00 \%. Keadaan tersebut menunjukkan bahwa guru SMA Negeri 14 kurang berkompeten dalam pembelajaran, sehingga prestasi belajar siswa dilihat dari hasil ujian nasional tahun 2018 menjadi rendah atau menurun dibanding pada tahun 2017. 


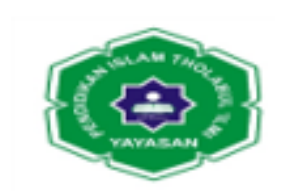

\section{Jurnal Ilmiah METADATA}

Guru SMA Negeri 14 pada semua mata pelajaran yang diujikan dalam ujian nasional belum mampu mencari atau mengembangkan metode pembelajaran yang tepat, sehingga siswa-siswi menjadi lebih lambat dalam memahami topik mata pelajaran. Hal ini disebabkan kedisiplinan guru masih kurang, guru sering terlambat masuk mengajar, bahkan guru absen mengajar tanpa pemberitahuan yang jelas. Semangat kerja yang masih rendah, banyak guru dalam mengajar masih menggunakan cara-cara tradisional dan belum sepenuhnya mengacu pada kurikulum dan kegiatan pembelajaran yang efektif dan efesien. Belum semua guru menyiapkan RPP pada saat mengajar sehingga tujuan pembelajaran yang ingin dicapai kurang jelas.

Pada saat melaksanakan tugas guru memiliki sifat dan perilaku yang berbeda, ada yang bersemangat dan penuh tanggung jawab, juga ada guru yang dalam melakukan pekerjaan itu tanpa rasa tanggung jawab. Masih banyak guru yang memilih profesi sebagai guru bukan karena panggilan jiwa, di duga juga ada guru-guru tidak bangga dengan profesinya, dan ia kurang menunjukkan tanggung jawab sebagai guru.

\section{METODOLOGI PENELITIAN}

Penelitian ini di lakukan pada SMA Negeri 14 Medan. Penelitian ini dijadwalkan pada bulan April 2018 s/d Juni 2018. Penelitian ini dilakukan dengan metode kuantitatif. Jenis penelitian adalah asosiatif, yaitu dengan mengumpulkan data atas kejadian yang menjadi permasalahan, kemudian menganalisis data untuk menelusuri penyebab terjadinya masalah. Penelitian ini menghasilkan kesimpulan dan saran untuk ditindaklanjuti sebagai tindakan korektif untuk mengatasi permasalahan yang terjadi. Data yang dikumpulkan meliputi dua variabel bebas yakni disiplin kerja $\left(\mathrm{X}_{1}\right)$ dan sikap inovatif $\left(\mathrm{X}_{2}\right)$ serta satu variabel terikat yaitu kinerja guru $(\mathrm{Y})$.

Populasi penelitian ini berjumlah 50 orang guru. Populasi atau jumlah guru yang mengajar di SMA Negeri 14 Medan lebih kecil dari 100 orang, sehingga seluruh populasi yang berjumlah 50 orang diambil sebagai sampel, yang disebut dengan metode pengambilan sampel secara sensus atau sampel jenuh.

\section{HASIL PENELITIAN DAN PEMBAHASAN}

\section{A. Deskripsi Variabel Penelitian}

\section{Tanggapan Responden Tentang Disiplin Kerja}

Prinsip dasar dari disiplin kerja adalah mengutamakan pekerjaan dibanding kegiatan lainnya. Dengan adanya disiplin maka seseorang akan berusaha untuk hadir di tempat kerja dan selalu siap sedia untuk melakukan pekerjaannya, dengan mematuhi segala peraturan yang ditetapkan.

Tabel 3.

Statistik Deskriptif Disiplin Kerja 


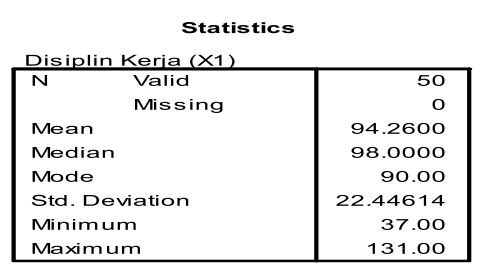

Sumber: Hasil Pengolahan Data SPSS

Berdasarkan Tabel 14 di atas, diketahui nilai mean sebesar 94,26, maka persentase nilai kecenderungan disiplin kerja adalah sebesar 94,26/135 x $100 \%=$ $69,82 \%$. Bila dibandingkan dengan nilai rata-rata pengkategorian, maka nilai berada pada rentang 51\%-75\%. Dari hasil tersebut dapat disimpulkan bahwa pandangan responden tentang disiplin kerja guru SMA Negeri 14 Medan kategori baik sebesar 69,82\%.

Tanggapan Responden Tentang Sikap Inovatif

Sikap inovatif sangat diperlukan untuk mengembangkan pikiran dan mengembangkan cara kerja, sehingga kinerja yang lebih baik dapat diperoleh. Keadaan tersebut disebabkan cara-cara lama cenderung tidak dapat untuk selalu dipertahankan karena adanya perubahan terhadap segala sesuatu yang terkait dengan pekerjaan.

\section{Tabel 4.}

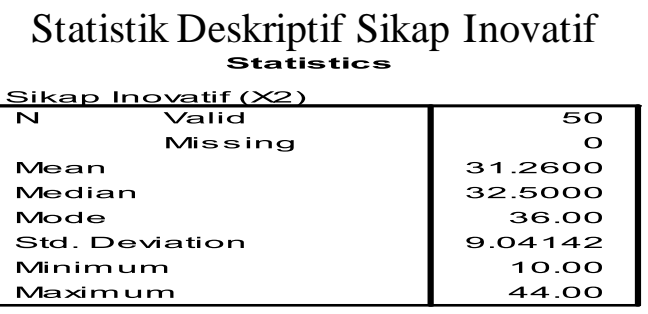

Sumber: Hasil Pengolahan Data SPSS

Berdasarkan Tabel 16 di atas, diketahui nilai mean sebesar 31,26, maka persentase nilai kecenderungan sikap inovatif adalah sebesar 31,26/135 x $100 \%=$ $69,69 \%$. Bila dibandingkan dengan nilai rata-rata pengkategorian, maka nilai berada pada rentang 51\%-75\%. Dari hasil tersebut dapat disimpulkan bahwa pandangan responden tentang sikap inovatif guru SMA Negeri 14 Medan kategori baik sebesar 69,69\%.

\section{Tanggapan Responden Tentang Kinerja Guru}

Kinerja yang tinggi sangat diperlukan untuk mencapai tujuan pembelajaran, karena tanpa kinerja yang tinggi dari seorang guru maka dapat dipastikan proses belajar tidak akan berhasil secara efektif menyampaikan materi pelajaran kepada siswa. 


\section{을}

Jurnal Ilmiah METADATA

Tabel 5.

Statistik Deskriptif Kinerja Guru statistics

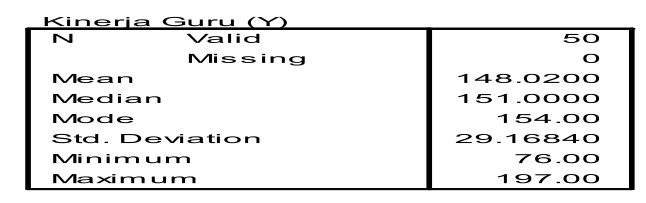

Sumber: Hasil Pengolahan Data SPSS

Berdasarkan Tabel 18 di atas, diketahui nilai mean sebesar 148,02, maka persentase nilai kecenderungan kinerja guru adalah sebesar 148,02/210 x $100 \%=$ $70,00 \%$. Bila dibandingkan dengan nilai rata-rata pengkategorian, maka nilai berada pada rentang 51\%-75\%. Dari hasil tersebut dapat disimpulkan bahwa pandangan responden tentang kinerja guru SMA Negeri 14 Medan kategori baik sebesar $70,00 \%$.

\section{B. Pengujian Hipotesis dan Pembahasannya \\ 1. Uji Asumsi Klasik \\ a. Uji Normalitas}

Uji normalitas menguji apakah dalam sebuah model regresi, variabel bebas dan variabel terikat, atau keduanya mempunyai distribusi normal atau tidak. Model regresi yang baik adalah distribusi data normal atau mendekati normal. Deteksi normalitas dengan melihat penyebaran data (titik) pada sumbu diagonal dari grafik.

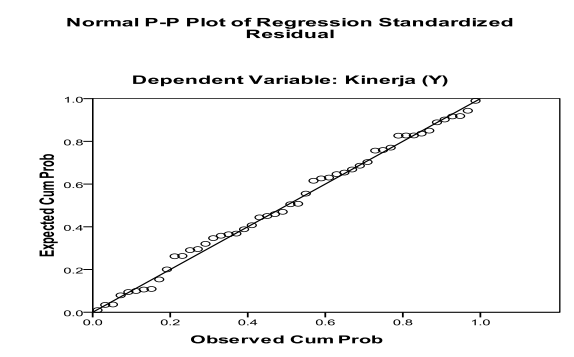

Gambar 1. Normal P-P Plot

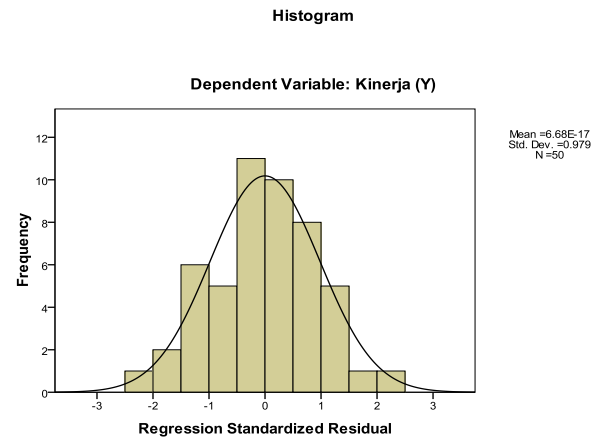


Gambar 2. Histogram

\section{c. Uji Multikolinearitas}

Uji multikolinearitas dilakukan untuk mengatahui ada tidaknya hubungan linear diantara variabel bebas dalam model regresi. Hasil SPSS pada Lampiran menunjukkan tidak ada gejala multikolinearitas dimana hasil uji VIF menunjukkan nilai kurang dari 10 (VIF < 10). Berdasarkan Tabel 20 disiplin kerja memiliki VIF 2.591 dan sikap inovatif memiliki VIF 2.591.

Tabel 6.

Uji Multikolinieritas

Coefficients $^{\mathrm{a}}$

\begin{tabular}{|lc|r|r|}
\hline \multirow{2}{*}{ Model } & \multicolumn{2}{|c|}{ Collinearity Statistics } \\
\cline { 3 - 4 } & Tolerance & \multicolumn{1}{c|}{ VIF } \\
\hline 1 & Disiplin kerja (X1) & .386 & 2.591 \\
& Sikap inovatif (X2) & .386 & 2.591 \\
\hline
\end{tabular}

a. Dependent Variable: Kinerja $(Y)$

Sumber: Diolah dengan SPSS

\section{Pengujian Hipotesis}

\section{Pengujian Secara Parsial (Uji t)}

Uji parsial dilakukan untuk mengetahui hubungan secara parsial antara variabel bebas terhadap variabel terikat berikut:

Tabel 7.

Coefficients Uji t

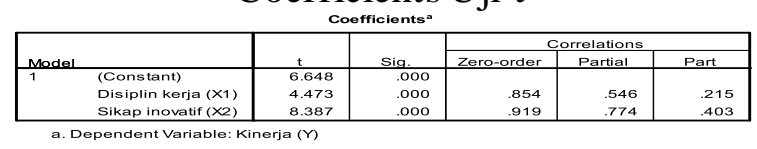

Sumber: Diolah dengan SPSS

Dari Tabel 21 dapat diketahui bahwa:

1. Koefisien korelasi antara disiplin kerja dengan kinerja guru adalah sebesar 0.546 . Koefisien korelasi tersebut bertanda positif $(+)$ yang berarti semakin baik disiplin kerja maka kinerja guru juga akan semakin tinggi. Nilai t-hitung untuk variabel disiplin kerja adalah sebesar 4,473> 2,012 dengan tingkat signifikansi sebesar $0,000<0,05$, sehingga $\mathrm{H}_{0}$ ditolak dan $\mathrm{H}_{\mathrm{a}}$ diterima. Dengan demikian, secara parsial variabel disiplin kerja mempunyai hubungan signifikan dengan kinerja guru.

2. Koefisien korelasi antara sikap inovatif dengan kinerja guru adalah sebesar 0,774 . Koefisien korelasi tersebut bertanda positif (+) yang berarti semakin baik sikap inovatif maka kinerja guru juga akan semakin tinggi. Nilai t-hitung untuk variabel sikpa inovatif adalah sebesar 8,387 > 2,012 dengan tingkat signifikansi sebesar $0.000<0,05$, sehingga $\mathrm{H}_{0}$ ditolak dan $\mathrm{H}_{\mathrm{a}}$ diterima. Dengan demikian, 
secara parsial variabel sikap inovatif mempunyai hubungan signifikan dengan kinerja guru.

Koefisien korelasi antara disiplin kerja dan sikap inovatif dengan kinerja dapat dilihat pada Tabel 4.14.

Tabel 8.

Koefisien Korelasi $\mathrm{X}_{1} \mathrm{X}_{2} \mathrm{Y}$

Model Summary ${ }^{\mathrm{b}}$

\begin{tabular}{|c|r|r|r|r|}
\hline Model & RX1X2Y & R Square & \multicolumn{1}{c|}{$\begin{array}{c}\text { Adjusted R } \\
\text { Square }\end{array}$} & $\begin{array}{c}\text { Std. Error of } \\
\text { the Estimate }\end{array}$ \\
\hline 1 & $.944^{\mathrm{a}}$ & .892 & .887 & 9.80702 \\
\hline
\end{tabular}

a. Predictors: (Constant), Sikap inovatif (X2), Disiplin kerja

Sumber: Diolah dengan SPSS

Berdasarkan Tabel 22 dapat dilihat bahwa nilai $\mathrm{RX}_{1} \mathrm{X}_{2} \mathrm{Y}$ adalah 0,944, artinya hubungan disiplin kerja dan sikap inovatif dengan kinerja guru adalah sangat kuat, dimana nilai $\mathrm{R}=0,944$ dibandingkan dengan interprestasi koefisien (Tabel 3.7) terlihat interval koefisien 0,80 - 1,00 mempunyai tingkat hubungan sangat kuat.

\section{Pengujian Secara Simultan (Uji F)}

Pengujian secara simultan atau serempak dilakukan untuk mengetahui bagaimana hubungan antara disiplin kerja dan sikap inovatif dengan kinerja guru. Signifikansi hubungan tersebut dapat dilihat dengan membandingkan $\mathrm{F}$ hitung dan $\mathrm{F}$ tabel pada tingkat signifikan $(\alpha)=5 \%$. Hasil pengujian secara simultan dari program SPSS dapat dilihat pada Tabel 4.15.

Tabel 9. Uji F

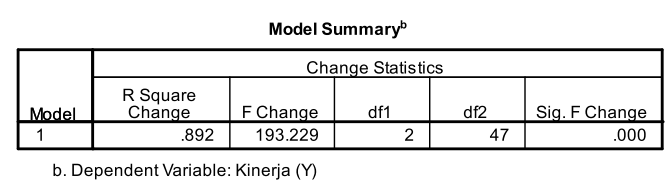

Sumber: Diolah dengan SPSS

Tabel 23 diatas menunjukkan bahwa secara simultan variabel disiplin kerja dan sikap inovatif mempunyai hubungan yang signifikan dengan kinerja guru. Hubungan signifikan tersebut ditunjukkan pada nilai $F_{\text {hitung }}$ sebesar 193,229 $>F_{\text {tabel }}$ sebesar 3,195. Dengan demikian diambil keputusan maka $\mathrm{H}_{0}$ ditolak dan $\mathrm{H}_{\mathrm{a}}$ diterima, artinya bahwa secara simultan variabel disiplin kerja dan sikap inovatif mempunyai hubungan yang signifikan dengan kinerja guru pada SMA Negeri 14 Medan.

\section{Pengujian Determinasi $\left(\mathbf{R}^{2}\right)$}


Koefisien determinasi (R Square) digunakan untuk mengetahui sejauh mana variabel terikat kinerja guru dapat dijelaskan oleh variabel bebas disiplin kerja dan sikap inovatif. Berdasarkan print out SPSS diperoleh hasil sebagai berikut:

Tabel 10. R Square

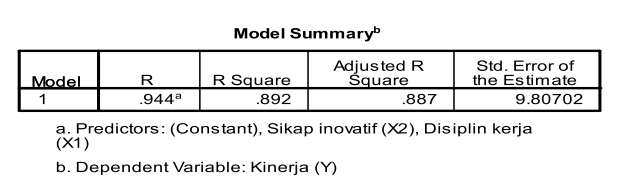

Sumber: Diolah dengan SPSS

Berdasarkan Tabel 24 dapat dilihat bahwa koefisien determinasi $\mathrm{R}^{2}$ adalah sebesar 0.895. Artinya 89.20\% variasi kinerja guru dapat dijelaskan oleh disiplin kerja dan sikap inovatif secara serempak, sedangkan sisanya $10.8 \%$ lagi dijelaskan oleh faktor lain, yaitu seperti variabel motivasi dan gaya kepemimpinan.

\section{Pembahasan Hasil Penelitian}

\section{Hubungan Disiplin Kerja dengan Kinerja Guru SMA Negeri 14 Medan}

Berdasarkan hasil penelitian yang telah dianalisis secara statistik diketahui bahwa secara parsial disiplin kerja mempunyai hubungan yang positif dan signifikan dengan kinerja guru SMA Negeri 14 Medan. Semakin baik disiplin kerja maka kinerja guru juga akan semakin baik.

Hasil tersebut di atas mengartikan bahwa kinerja guru SMA Negeri 14 Medan dapat ditingkatkan dengan memperbaiki disiplin kerjanya. Keadaan tersebut disebabkan masih terdapat unsur-unsur disiplin yang diterapkan secara kurang baik.

Menurut responden bahwa unsur disiplin yang kurang baik adalah guru tidak disiplin mencatat hal-hal penting dalam proses belajar mengajar, tidak disiplin menyelesaikan pekerjaan sesuai dengan waktu yang ditentukan, serta tidak berusaha agar pekerjaan lebih cepat selesai dari waktu yang ditentukan. Dengan memperbaiki ketiga unsur tersebut maka disiplin kerja pada sekolah tersebut akan semakin baik, sehingga kinerja guru juga akan semakin tinggi.

Mencatat hal-hal penting dalam proses belajar seharusnya dilakukan agar segala sesuatu tentang proses belajar dapat dengan mudah diingat oleh guru. Halhal penting tersebut seperti topik yang sulit dipahami, batas-batas materi pembelajaran, hal-hal baru yang muncul pad a saat pembelajaran berlangsung, siswa yang aktif dalam belajar dan siswa yang kurang aktif, serta keadaan kelas pada saat pembelajaran. Dengan melakukan pencatatan terhadap keadaan-keadaan kelas 


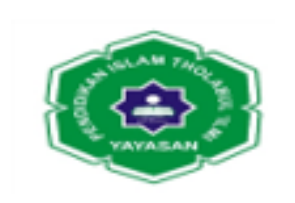

\section{Jurnal Ilmiah METADATA}

maka akan lebih mudah bagi guru untuk memulai pembelajaran berikutnya serta mengatasi permasalahan yang timbul dalam pembelajaran.

Guru juga seharusnya menyelesaikan pekerjaan secara tepat waktu, dan bahkan harus selalu berusaha agar pekerjaan dapat lebih cepat dari waktu yang telah ditentukan. Unsur waktu penyelesaian pekerjaan merupakan salah satu unsur kinerja sehingga unsur tersebut selalu menjadi fokus perhatian dari setiap instansi. Pada dasarnya guru mempunyai banyak waktu untuk menyelesaikan pekerjaannya karena pekerjaan guru selain mengajar dapat dilakukan dimana saja termasuk juga di rumah. Melakukan pekerjaan dirumah tidak akan mengganggu kegiatan lainnya karena guru dapat membagi waktunya dengan baik antara pekerjaan rumah dengan pekerjaan sekolah.

\section{Hubungan Sikap Inovatif dengan Kinerja Guru SMA Negeri 14 Medan}

Berdasarkan hasil penelitian yang telah dianalisis secara statistik diketahui bahwa secara parsial sikap inovatif mempunyai hubungan yang positif dan signifikan dengan kinerja guru SMA Negeri 14 Medan. Semakin baik sifat inovatif maka kinerja guru juga akan semakin baik. Dengan demikian bahwa kinerja guru SMA Negeri 14 Medan juga dapat ditingkatkan dengan memperbaiki sikap inovatifnya.

Menurut responden bahwa masih terdapat keselamahn dalam sikap guru yang tidak sesuai dengan sikap inovatif. Hal tersebut dapat dilihat dari guru yang kurang aktif mencari informasi tentang inovasi baru dalam pembelajaran, serta tidak selalu aktif mencoba mengembangkan metode pembelajaran yang dapat secara efektif mempercepat siswa memahami materi pelajaran.

Guru harusnya aktif mencari informasi dari berbagai sumber yang tersedia tentang cara-cara baru dalam metode pembelajaran yang dapat diterapkan untuk meningkatkan pemahaman siswa terhadap materi pelajaran. Guru dapat mencarinya dari media informasi yang pada zaman sekarang sudah tergolong menjamur, seperti koran dan majalah, serta media elektronik. Guru dapat menelusuri informasi nasional dan internasional dengan menggunakan internet sehingga memperoleh informasi tersebut sebenarnya tidaklah sulit. Jika guru berperilaku aktif maka sangat banyak informasi tentang inovasi baru yang dapat dipelajari.

Guru juga seharusnya selalu aktif mencoba mengembangkan metode pembelajaran yang dapat secara efektif mempercepat siswa memahami materi pelajaran. Guru yang secara langsung berhadapan dengan siswa tentu lebih mengenal segala sesuatu yang berhubungan dengan proses belajar di kelas, sehingga dengan lebih mudah dapat mencari metode pembelajaran baru yang sesuai dengan keadaan kelasnya. Perlu disadari bahwa metode pembelajaran yang efektif tidak hanya menguntungkan siswa dalam belajar tetapi juga menguntungkan guru 
dalam mengajar, karena pada umumnya metode yang efektif akan menghemat waktu dan usaha yang diperlukan hingga pelajaran dapat diterima dengan baik oleh para siswa.

\section{Hubungan Disiplin Kerja dan Sikap Inovatif dengan Kinerja Guru SMA Negeri 14 Medan}

Berdasarkan hasil penelitian yang telah dianalisis secara statistik diketahui bahwa nilai Fhitung sebesar 193,229 > F tabel sebesar 3,195 menunjukkan secara simultan variabel disiplin kerja dan sikap inovatif mempunyai hubungan yang signifikan dengan kinerja guru pada SMA Negeri 14 Medan.

Kinerja guru merupakan hal yang sangat penting dalam pencapaian tujuan suatu sekolah. Dengan tingkat pendidikan seorang guru dan adanya pelatihan diharapakan kinerja guru dapat optimal sehingga guru menjadi lebih disiplin dan bersikap inovatif. Disiplin kerja guru yang merupakan sikap terhadap peraturan sekolah dalam rangka pelaksanaan kerja meliputi: ketepatan waktu, kesadaran, menjalin hubungan yang baik dengan rekan kerja dan tingkah laku yang baik. Dalam bidang pendidikan, inovasi diterapkan dengan cara memperkenalkan program kurikulum baru atau metodologi pengajaran yang baru sebagai upaya untuk meningkatkan kualitas pendidikan.

\section{KESIMPULAN}

Berdasarkan hasil penelitian disimpulkan bahwa:

1. Variabel disiplin kerja mempunyai hubungan yang positif dan signifikan dengan kinerja guru SMA Negeri 14 Medan, dengan nilai t-hitung untuk variabel disiplin kerja adalah sebesar 4,473> 2,012 dan tingkat signifikansi sebesar $0,000<0,05$. Semakin tinggi tingkat disiplin guru maka kinerja guru juga akan semakin tinggi.

2. Variabel sikap inovatif mempunyai hubungan yang positif dan signifikan dengan kinerja guru SMA Negeri 14 Medan, dengan nilai t-hitung untuk variabel sikpa inovatif adalah sebesar 8,387 > 2,012 dengan tingkat signifikansi sebesar $0,000<0,05$. Semakin inovatif sikap guru maka kinerja guru juga akan semakin tinggi.

3. Variabel disiplin kerja dan sikap inovatif secara serempak mempunyai hubungan yang signifikan dengan kinerja guru SMA Negeri 14 Medan, dengan nilai Fhitung sebesar 193,229> F tabel sebesar 3,195. Sebesar 89,2 \% variasi kinerja guru dapat dijelaskan oleh disiplin kerja dan sikap inovatif secara serempak, sedangkan sisanya $10,80 \%$ lagi dijelaskan oleh faktor lain, yaitu seperti variabel motivasi dan gaya kepemimpinan.

\section{DAFTAR PUSTAKA}


Alfred, R. Lateiner. 2012. Teknik Memimpin Pegawai dan Pekerja. Terjemahan. Imam Soedjono. Jakarta: Aksara Baru.

Anwar, Q. 2009. Profesi Jabatan Kependidikan dan Guru Sebagai Upaya Manajemen Kualitas Pembelajaran. Jakarta: Uhanika Press.

Davis, Keith. 2013. Perilaku dalam Organisasi, Terjemahan Agus Darma, Jakarta: Erlangga.

Dessler, Gary. 2011. Manajemen Sumber Daya Manusia. Jakarta: Indeks.

Ghozali, Imam. 2012. Aplikasi SPSS. Semarang: Badan Penerbit Diponegoro.

Gibson, James I. 2011. Organisasi Perilaku, Struktur dan Proses. Terjemahan Agus Dharma, Jakarta: Erlangga.

Griffin, E. 2010. Kinerja Guru. Jakarta: Indeks.

Handoko, T. Hani, 2013, Manajemen Personalia dan Sumber Daya Manusia, Yogyakarta: BPFE.

Hasibuan, Malayu, S.P., 2010, Manajemen: Dasar, Pengertian, dan Masalah, Jakarta: Bumi Aksara.

Heidjrachman, Ranupandojo dan Suad Husnan. 2010. Manajemen Personalia. Yogyakarta: BPFE.

Hurlock, Elizabeth B. 1910. Perkembangan Anak. Jakarta: Erlangga.

Ibrahim. 2012. Inovasi Pendidikan. Jakarta: Ditjen Dikti Depdikbud.

Jasmani. 2016. Hubungan Antara Sikap Inovatif dan Kepemimpinan Kepala Sekolah dengan Kinerja Guru di SD Negeri Sekecamatan Ketahuan. Jurnal Manajer Pendidikan, Volume 10, Nomor 3, Juli 2016.

Kusmianto. 2012. Panduan Penilaian Kinerja Guru Oleh Pengawas. Jakarta: Bina Aksara.

Mahsun, Mohamad.2010. Pengukuran Kinerja. Yogyakarta: BPFE.

Mangkunegara. 2013. Manajemen Sumber Daya Manusia. Bandung: Remaja Roskdakarya. 
Mathis, Robert L. dan Jhon H. Jackson. 2012. Manajemen Sumber Daya Manusia. Terjemahan: Jimmy Salibi dan Bayu Prawira. Jakarta: Salemba Empat.

Matondang, Zulkifli. 2012. Hubungan Efektifitas Pengawasan dan Sikap Inovasi dengan Kinerja Guru SMP Sub Rayon 2 Kota Medan. Jurnal Tabularasa PPS Unimed Vol. 9 No.1, Juni 2012.

Mulyasa. 2011. Menjadi Guru Profesional. Bandung: Remaja Rosdakarya.

Nawawi, H. Hadari. 2010. Perencanaan SDM, Yogyakarta: Gadjah Mada University Press, Yogyakarta.

Notoatmodjo, Soekidjo. 2010. Pengembangan Sumber Daya Manusia. Jakarta:Rineka Cipta.

Pakpahan, L. 2005. Hubungan Sikap Inovasi dan Pemberian Kompensasi Dengan Prestasi Kerja Guru SMA Negeri di Kota Medan. Tesis: PPS Unimed.

Purba, S. 2015. Pengaruh Budaya Organisasi, Modal Intelektual, dan Perilaku Inovatif terhadap Kinerja Pemimpin Jurusan di Universitas Negeri Medan. Kinerja, Volume 13, No.2. pp 150-167.

Rivai, Veithzal. 2012. Manajemen Sumber Daya Manusia UntukPerusahaan Dari Teori Ke Praktek. Bandung. Rajagrafindo Persada.

Saondi. 2010. Etika Profesi Keguruan. Bandung: Rafika Aditama.

Sastrohadiwiryo. 2012. Manajemen Sumber Daya Manusia, Jakarta: Djambatan.

Singodimedjo. 2010. Menejemen Sumber Daya Manusia. Jakarta: Bumi Aksara.

Sinulingga, Lajuhardi Purnama. 2016. Pengaruh Disiplin Kerja, Sikap Inovatif, dan Motivasi Kerja Terhadap Kinerja Guru Gugus IV SD di Kecamatan Kutalimbaru Kabupaten Deli Serdang. Jurnal Manajemen Vol 1.

Sofyandi. 2011. Kinerja Guru. Jakarta: Bina Aksara.

Stolovitch, H.D. 2006. Handbook of Human Performance Technology. USA: Pfeiffer.

Stoner, J.A.F dan R.E. Freeman. 2010. Manajemen. Jakarta: Intermedia. 


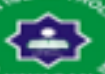

Jurnal Ilmiah METADATA

Sugiyono. 2012. Metode Penelitian Bisnis. Bandung: Alfabeta.

Werther, William dan Keith Davids. 2011. Manajemen Personalia dan Sumber Daya Manusia. Jakarta: Indeks.

Wursanto. 2012. Kinerja Kepegawaian. Jakarta: Rineka Cipta.

Yamin, Martinis dan Maisah. 2010. Standarisasi Kinerja Guru. Jakarta: Gaung Persada. 